Meta

Journal des traducteurs

Translators' Journal

\title{
The Translation of Hentai, Japanese Animated Pornography
}

Daniel E. Josephy-Hernández

Volume 60, numéro 2, août 2015

$60^{\mathrm{e}}$ anniversaire. Les horizons de la traduction : retour vers le futur

$60^{\text {th }}$ Anniversary. Translation's Horizons: Back to the Future

60mo aniversario. Los horizontes de la traducción: regreso al futuro

URI : https://id.erudit.org/iderudit/1032896ar

DOI : https://doi.org/10.7202/1032896ar

Aller au sommaire du numéro

Éditeur(s)

Les Presses de l’Université de Montréal

ISSN

0026-0452 (imprimé)

1492-1421 (numérique)

Découvrir la revue

Citer ce document

Josephy-Hernández, D. E. (2015). The Translation of Hentai, Japanese Animated Pornography. Meta, 60(2), 345-345. https://doi.org/10.7202/1032896ar 


\title{
The Translation of Hentai, Japanese Animated Pornography
}

\author{
DANiEl E. Josephy-HernándeZ \\ University of Ottawa. Ottawa, Canada \\ djose083@uottawa.ca
}

Hentai (Japanese animated pornography) is a popular form of pornography both inside and outside Japan. Its fanbase is mostly men, but women also watch it. Hentai is a "type of erotica frequently characterized by detailed, unusual and fantastic depictions of sexual activity habitually intended for sexual arousal" (Ortega-Brena 2008), with plots of various kinds, ranging from hetero and homosexual relationships, to rape, incest and events unique to hentai, such as sex transformation, and fantastical events involving tentacles.

Since hentai has been successfully exported and marketed outside of Japan, this presentation provides a historical overview of hentai, and an analysis of how it has been translated in the US. Hentai, like most anime nowadays, is foreignised as much as possible (Josephy-Hernández 2015), yet hentai (and anime in general) has suffered much censorship over the years. This censorship can be of various types, e.g., a visual, content or semantical one, with some hentai banned altogether from a US release. Nonetheless, viewers can now circumvent, online, whatever legal barrier was originally in place, as plenty of raw (untranslated) and fansubbed versions of banned material (both old and new) can now be found in specific websites, with fansubbing groups acting not only as the fansubbers of a specific show, but also as the distributors/providers of it, even if it is not legal to view it in the US. Even if hentai is controversial both inside and outside of Japan, it is imperative to analyse the role hentai has in the dissemination of specific gender and social values, and the part that companies and fansubbers play in it.

Daniel E. Josephy-Hernández is writing a PhD dissertation about the translation of the Japanese animation "Sailor Moon" from a gender perspective. He recently spent a research period at Tohoku Gakuin University in Sendai, Japan. His research fields include translation studies, anime, interpreting, Canadian literature, teaching, and graphic novels. He has knowledge of 13 languages (including Japanese and Welsh) and a vast understanding of anime. 